\title{
AUTHORSHIP PATTERNS IN JOURNAL OF ORGANIC CHEMISTRY: AN ANALYTICAL STUDY
}

\author{
Ahirrao M.K. ${ }^{1}$; Sonawane S.S. ${ }^{2}$ \\ Librarian, S.P.D.M. Arts, Commerce \& Science College, Shirpur-425405 \\ Associate Professor, Dept. of Library and Information Science, Dr. Babasaheb Ambedkar Marathwada \\ University, Aurangabad, (MS) India-431001² \\ mkahirrao066@gmail.com ${ }^{1}$; shashank65@yahoo.com ${ }^{2}$
}

\begin{abstract}
Presents a case study of the trends in authorship pattern and collaborative research in Jourmal of Organic Chemistry. The study concluded that out of 6689 articles, the single author contributed $1.55 \%$ of articles while $82.68 \%$ articles were contributed by more than one authors. The study reveal that most of the contributions are from USA with 6983 authors and India contributes 1504 authors.
\end{abstract}

Keywords: Bibliometries, Authorship pattern, Degree of Collaboration, Scientometrics, Informetrics.

\section{INTRODUCTION}

Authorship trend and collaborative research are important facets of scientometric, studies. The authorship pattern, one of prime aspects of Bibliometric analysis mainly deals with the kind of authors, nature and degree of collaboration among them and collaborative trend of authors. Multiple authorship has been a characteristics feature of the social science and there has been consistent trends towards increased collaboration in all the branches of social science collaboration and them work are among the most important necessities sociological work today. In recent period, there is a trend towards collaboration in research in branches of Organic Chemistry. Twenty first century has been collaborative research trend among scientists working in groups within and across the geographic boundaries of a country.

\section{REVIEW OF LITERATURE}

Dongare Sudesh N. and Khaparde Vaishali .S. $(2015)^{1}$ made study on Scientometric Analysis Of Library Herald Journal. Focussed on geographical distribution, highly contributed authors in journal. That of the most contributions are from India with $75.49 \%$ and the rest $24.50 \%$ only from foreign sources.Fawaz Abdullah Alhamdi and Khaparde Vaishali (2015) ${ }^{2}$ made study on Authorship And Collaborative Patterns In The Annals Of Library And Information Studies, 2007-2013: A Scientometric Study. It consists of the Relative Growth Rates [R(c)] and Doubling Time [Dt(c)] for publication, Geographical distribution of contributions by state. Found that The whole study period records the mean relative growth rate of $\mathbf{0 . 3 0 7}$. Contrarily, the doubling time for publication of all sources of output has increased from 0.855 in 2007 to 4.125 in 2010. The doubling time for publications at the aggregate level has been computed as 2.339 years. Khandare Sharad Prabhakar and Sonwane Shashank $(2016)^{3}$ made a study on Content Analysis Of "World Journal Of Microbiology And Biotechnology". It consist of year-wise growth of publications, Geographical distribution of research output, the authorship and collaboration pattern in the publication, the extent of international collaboration, the most productive authors in the field. 
Found that China is the top producing country with 2901publications (36.98) of the total output. Khaparde Vaishali and Pawar Shubhangi (2013) ${ }^{4}$ made study on Authorship Pattern and Degree of Collaboration in Information Technology. It consists of the nature of authorship patterns in information Technology, degree of collaboration on information technology. Found that in the degree of collaboration of all years i.e. from 2000-2009 is almost same of the mean value as0.49 whereas the degree of collaboration during the overall 10 years is 0.71 . Sonwane Shashank S. and Harne Shyam B. $(2015)^{5}$ conducted study of Content Analysis Of "Annals Of Biomedical Engineering Journal". This study focuses year-wise growth of publications, Geographical distribution of research output, the authorship and collaboration pattern in the publication. Found that USA is the top producing country with 3271 publications (57.79) of the total output. Sonwane Shashank and Navghare Sindhu V. (2015) ${ }^{6}$ conducted study of Content Analysis Of "International Journal Of Social Economics" This study focuses the Year-wise growth of publications, Geographical distribution of research output, the authorship and collaboration pattern in the publication, the extent of international collaboration. The most productive authors in the field. Yasinullah Shafiullah, Khaparde Vaishali and Fawaz Abdullah Alhamdi (2015) ${ }^{7}$ made study on The Electronic Library Journal: A bibliometric study (2010 to 2014). Focussed on the number of articles published per volume in each specific year, authorship patterns. Found that As DC value is more than 0.5, it is evident that multiple authored articles occupy the prominent position indicating the supremacy of solo research in the "The Electronic Library".

\section{OBJECTIVES}

The objectives of the present study are to find out the trend of research collaboration in the field of articles in the Library and information science Abstract journals.

- To examine the authorship pattern in the field of articles in Journal of Organic Chemistry

- To study the single vs multi-authored papers and average number of authors.

- $\quad$ To determine the degree of collaboration of Journal of Organic Chemistry.

\section{SCOPE AND LIMITATION}

This study is limited Articles published in 2009 to 2013.

\section{METHODOLOGY}

The study has been carried out by collecting 6689 articles from Journal of Organic Chemistry during 2009 to 2013 with a view to identify the extent of research conducted by individuals in collaboration with each other, the number of authors mentioned in the journals articles were recorded analyzed and tabulated for making observations.

Subramanyam proposed a mathematical formula for calculating authors degree of collaboration in a discipline. The degree of collaboration among authors is the ratio of the number of multiauthored papers published to the total number of papers published in a discipline during certain period of time. The degree of collaboration (collaboration coefficient) among authors is measured mathematically as:

$c=\frac{\mathrm{Nm}}{\mathrm{Nm}+\mathrm{Ns}}$

Where, $\mathrm{C}=$ Degree of Collaboration

$\mathrm{Nm}=$ Number of Multi Authored articles

Ns $=$ Number of Single Authored articles.

\section{Analysis and Results}

\subsection{Authorship pattern}

The authorship pattern of journal of organic chemistry publications were ascertained $\&$ the same is shown in Table. 
AUTHORSHIP PATTERNS IN JOURNAL OF ORGANIC CHEMISTRY: AN ANALYTICAL STUDY

Table No.1

\begin{tabular}{|l|l|l|l|l|}
\hline SR No. & No. Of Authors & Publications & Percentage & Cumulative \% \\
\hline 01 & Single Authors & 104 & 1.5547 & 1.5547 \\
\hline 02 & Two Authors & 1054 & 15.7572 & 17.3120 \\
\hline 03 & Three Authors & 1419 & 21.2139 & 38.5259 \\
\hline 04 & Four Authors & 1339 & 20.0179 & 58.5438 \\
\hline 05 & Five Authors & 1094 & 16.3552 & 74.8990 \\
\hline 06 & Six \& above Authors & 1679 & 25.1009 & 100.0000 \\
\hline & Total $=$ & 6689 & 100.0000 & \\
\hline
\end{tabular}

It can be observed that contribution of multiple author about $98.55 \%$ while single author was about only $1.55 \%$

\subsection{Single v/s Multiple Authored Articles}

\section{Table No.2}

\begin{tabular}{|l|l|l|l|l|l|l|l|}
\hline $\begin{array}{l}\text { Sr. } \\
\text { No. }\end{array}$ & Vol.No. & Year & $\begin{array}{l}\text { Single Authors } \\
\text { Paper }\end{array}$ & $\%$ & $\begin{array}{l}\text { Multiple Authors } \\
\text { Papers }\end{array}$ & $\begin{array}{l}\text { Total } \\
\text { Papers }\end{array}$ \\
\hline 1 & 74 & 2009 & 31 & 0.4634 & 1448 & 21.6475 & $\mathbf{1 4 7 9}$ \\
\hline 2 & 75 & 2010 & 8 & 0.1196 & 1189 & 17.7755 & $\mathbf{1 1 9 7}$ \\
\hline 3 & 76 & 2011 & 19 & 0.284 & 1259 & 18.8219 & $\mathbf{1 2 7 8}$ \\
\hline 4 & 77 & 2012 & 17 & 0.2541 & 1288 & 19.2555 & $\mathbf{1 3 0 5}$ \\
\hline 5 & 78 & 2013 & 29 & 0.4335 & 1401 & 20.9448 & $\mathbf{1 4 3 0}$ \\
\hline
\end{tabular}

It is found that the percentage of multi-authored papers are far more than that of single authored papers. In 2009 the percentage of multi authored papers was $21.65 \%$ while single authored papers was $0.46 \%$. In 2013 the percentage of single authored papers was found to be $0.43 \%$ while multi authored paper was $20.94 \%$. It indicates that "Teans" increasingly dominate over solo authors in the production of knowledge.

\subsection{Degree of Collaboration:}

To analyze the nature of researcher's participation in research activity, Authors productivity is tested.

To determine degree of collaboration in quantitative terms, the formula given by K. Subramaniyam was issued. The formula is: 
Table No.3

DEGREE OF COLLABORATION - YEARWISE

\begin{tabular}{|c|c|c|c|c|c|c|c|r|}
\hline $\begin{array}{c}\text { SR } \\
\text { NO. }\end{array}$ & Vol.No. & YEAR & $\begin{array}{c}\text { SINGLE } \\
\text { AUTHORS } \\
\text { PAPER }\end{array}$ & $\%$ & $\begin{array}{c}\text { MULTIPLE } \\
\text { AUHORS } \\
\text { PAPERS }\end{array}$ & $\%$ & $\begin{array}{c}\text { TOTAL } \\
\text { PAPERS }\end{array}$ & $\begin{array}{c}\text { DEGREE OF } \\
\text { COLLABORATION }\end{array}$ \\
\hline 1 & 74 & 2009 & 31 & 0.46345 & 1448 & 21.6475 & $\mathbf{1 4 7 9}$ & 0.9790 \\
\hline 2 & 75 & 2010 & 8 & 0.1196 & 1189 & 17.7755 & $\mathbf{1 1 9 7}$ & 0.9933 \\
\hline 3 & 76 & 2011 & 19 & 0.28405 & 1259 & 18.8219 & $\mathbf{1 2 7 8}$ & 0.9851 \\
\hline 4 & 77 & 2012 & 17 & 0.25415 & 1288 & 19.2555 & $\mathbf{1 3 0 5}$ & 0.9870 \\
\hline 5 & 78 & 2013 & 29 & 0.43355 & 1401 & 20.9448 & $\mathbf{1 4 3 0}$ & 0.9797 \\
\hline & & & $\mathbf{1 0 4}$ & & $\mathbf{6 5 8 5}$ & & $\mathbf{6 6 8 9}$ & \\
\hline
\end{tabular}

The degree of collaboration $=\mathrm{C}=\frac{\mathrm{Nm}}{(\mathrm{Nm}+\mathrm{Ns})}$

Where, $\mathrm{C}=$ Degree of collaboration in a discipline

$\mathrm{Nm}=$ number of multi authored papers in the discipline

Ns = number of single papers in the discipline

It shows that degree of collaboration of authors from journal of organic chemistry consistently increasingly over the years 2009 to 2010 and highest was recorded in the year 2010 with 0.99 which is the high degree of collaborative research in organic Chemistry. The Table shows that in 2010 it is decreased to 0.985 in 2011 again slightly increased to 0.987 and decreased to 0.9797 in 2013 but found high degree of collaboration through 2009 upto2013

\section{CONCLUSION}

Scientometric techniques are being used for a variety of purposes like determination of various scientific indicators, evaluation of scientific output, selection of journals for libraries and even forecasting the potential of a particular field.

The journal has published 6689 articles during the period of study. Percentage of multi-authored papers are far more than that of single authored papers. In 2009 the percentage of multi authored papers was $21.65 \%$ while single authored papers was $0.46 \%$. It has been found high degree of collaboration throughout 2009 upto2013.

\section{REFERENCES}

[1]. Dongare Sudesh N. and Khaparde Vaishali .S. (2015). Scientometric Analysis Of Library Herald Journal. Knowledge Librarian , 2 (1), 48-66.

[2]. Fawaz Abdullah Alhamdi and Khaparde Vaishali . (2015). Authorship And Collaborative Patterns In The Annals Of Library And Information Studies, 2007-2013: A Scientometric Study. International Journal of Digital Library Services , 5 (1), 117-129.

[3]. Khandare Sharad Prabhakar, Sonwane Shashank : (2016). Content Analysis Of "World Journal Of Microbiology and Biotechnology". International Journal of Digital Library Services , 6 (4), $42-52$.

[4]. Khaparde Vaishali, Pawar Shubhangi . (2013). Authorship Pattern and Degree of Collaboration in Information Technology. Journal of Computer Science \& Information Technology , 1 (1), 46-54.

[5]. Sonwane Shashank S. and Harne Shyam B. (2015). Content Analysis Of "Annals Of Biomedical Engineering Journal”. Knowledge Librarian , 2 (4), 142-160.

[6]. Sonwane Shashank, Navghare Sindhu V. (2015). Content Analysis Of "International Journal Of Social Economics". “ Knowledge Librarian" An Iiternational Peer Revieved Bilingual E-Journal Of Library And Information Science , 2 (3), $1-33$.

[7]. Yasinullah Shafiullah, Khaparde Vaishali and Fawaz Abdullah Alhamdi. (2015). The Electronic Library Journal: A bibliometric study (2010 to 2014). International Journal of Academic Library and Information Science , 3 (8), $226-235$. 